\title{
Peertechz
}

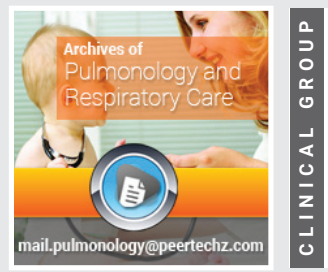

\section{Latent Multi-drug Resistant Tuberculosis: An Unaddressed Problem}

\author{
Gyanshankar Mishra ${ }^{1 *}$ and Jasmin Mulani ${ }^{2}$ \\ ${ }^{1}$ Associate Professor, Department of Respiratory Medicine, Indira Gandhi Government Medical \\ College, Maharashtra University of Health Sciences, Nagpur, India \\ ${ }^{2}$ Resident Medical Officer, Department of Biochemistry, Government Medical College, Nagpur, India
}

Received: 09 November, 2020

Accepted: 24 November, 2020

Published: 25 November, 2020

*Corresponding author: Dr. Gyanshankar Mishra, Associate Professor, Department of Respiratory Medicine, Indira Gandhi Government Medical College, Maharashtra University of Health Sciences, Nagpur, India, Tel: 9850349074; E-mail: gpmishra81@gmail.com

ORCID: https://orcid.org/0000-0002-0084-839X

Keywords: Latent MDR-TB; Tuberculosis; LTBI; Latent tuberculosis

https://www. peertechz.com

Check for updates

\begin{abstract}
It is estimated that three of every 1,000 individuals worldwide have latent Multidrug-Resistant Tuberculosis (MDR-TB) infection. Management of latent MDR-TB is an integral component in our strategies targeting global TB elimination. We are currently targeting only latent drug-sensitive TB as there are no consensus guidelines on the management of latent MDR-TB. Such an approach can potentially lead to a "fall and rise phenomenon" in latent MDR-TB. Risk factors for latent MDR-TB need to be identified, and high-risk individuals need to be screened and treated on priority for latent MDR-TB. The treatment of latent MDR-TB can be initiated primarily with fluoroquinolones-based treatment regimes. Such regimes need to be individualized based on the drug sensitivity pattern of the source case isolate of drug-resistant TB. Thus, strategies for managing latent MDR-TB are the need of the day.
\end{abstract}

It is estimated that three of every 1,000 individuals worldwide have latent MDR tuberculosis infection, and the incidence for those younger than 15 years is around ten times higher. If current trends persist, the proportion of latent Tuberculosis caused by MDR strains will increase, posing significant challenges to tuberculosis management $-\mathrm{a}$ cornerstone of tuberculosis elimination strategies [1].

Today, when globally, we target TB elimination as our main goal, it seems that targeting latent TB infection is the weak link. The approaches on a programmatic level predominantly target the drug-sensitive latent TB infection, with the problem of drug-resistant TB infection largely left unaddressed. Tackling Latent TB infection is more difficult as we do not have a reliable biomarker to monitor the therapeutic response of treatment of Latent TB Infection (LTBI) [2]. There is a hypothetical probability that only treating the drugsensitive latent TB infection and leaving the drug-resistant TB unaddressed could lead to an initial decrease in the overall LTBI population, with drug-sensitive LTBI population as a major component, followed by an increase in the overall LTBI population with drug-resistant LTBI population as a major component. This phenomenon could be akin to the "fall and rise phenomenon" responsible for the genesis of drug resistance in the bacillary population of mycobacterium Tuberculosis following a monotherapy regime [3]. However, our current lack of knowledge of dormant TB bacilli behaviour and the absence of clinically reliable biomarkers to monitor treatment outcomes in LTBI would make it difficult to accept or refute the above hypothesis.

Latent MDR-TB infected individuals can be broadly classified as contacts of known MDR-TB patients and unknown/undiagnosed MDR-TB patients' contacts. It is not easy to diagnose the latter group, and the current guidelines target only a select category of individuals in the former group. This can be ascertained from the fact that the World Health Organisation (WHO) guidelines on the management of LTBI currently recommends initiation of preventive MDR LTBI treatment based on individualized risk assessment and a sound clinical justification in selected high-risk household contacts (e.g. children, people on immunosuppressive therapy and People Living with HIV (PLHIV)) of patients with multidrugresistant Tuberculosis [4].

Previously, screening and treatment of LTBI in HIV negative 
population was limited to adults, adolescents and children who were household contacts of people with bacteriologically confirmed pulmonary TB in countries with low TB incidence. However, recently LTBI screening and treatment of the above population have been recommended even in countries with high TB incidence, a pragmatic shift in LTBI screening strategy to diagnose LTBI actively. Other than PLHIV, patients initiating anti-TNF treatment, patients receiving dialysis, patients preparing for an organ or hematological transplant and patients with silicosis are also considered high-risk groups for screening for LTBI. Also, in countries with a low TB incidence, additional LTBI testing and treatment of prisoners, health workers, immigrants from countries with a high TB burden, homeless people, and illicit drug abusers are currently recommended [4].

Undernutrition has been recognized as a risk factor for the progression of LTBI to active TB disease [5]. Hence measures aimed at tackling the undernutrition among people diagnosed with LTBI need to be focused on, which essentially translates into measures aimed to fight poverty and unite to improve the community's standard of living, especially in a developing country like India. Historically, this has been witnessed in the now developed countries, where TB-related mortality decreased since the Industrial Revolution [6].

A systematic review of 21 relevant papers found an estimated $90 \%$ reduction in MDR-TB incidence with preventive treatment. Preventive treatment of MDR-TB contacts with LTBI is recommended based on the above observation $[7,8]$. Currently, there is no established high-quality, evidencebased, precise guidance on the formulation of a treatment regime for MDR-LTBI, especially in the programmatic setup $[4,9]$. In this regard, the results of many ongoing trials are awaited, and it may be a reasonable practice to determine the preventive treatment of MDR-TB based on the drug sensitivity results of the Mycobacterium Tuberculosis isolate of the source case. If possible, a later generation fluoroquinolone alone or in combination with a second drug such as ethambutol should be used. In such a treatment regime, pyrazinamide's inclusion is usually precluded with the higher adverse drug reactions and discontinuations associated with its use. Other second-line medications may be an addition to the MDR-LTBI treatment if required, subject to the confirmed drug sensitivity in the source case $[8,9]$.

The following treatment regimens, broadly based on the source case TB isolate's drug resistance pattern suggested by the Curry International TB Center Drug-Resistant TB: Clinician's Survival Guide, may be utilized to manage MDRLTBI till more conclusive evidence is available on individualized treatment regimes [10] Table 1.

Treatment of MDR-LTBI is a decision that needs to weigh the benefit of preventing progression to MDR-TB disease visà-vis the therapy's potential side effects. Inclusion of treatment of MDR-LTBI needs to be included in the programmatic management of Tuberculosis. Thus, latent MDR-TB is a problem that cannot be left unaddressed anymore, and it is not an easy task to address the problem, considering the lack of evidence on its treatment as it is today.

Table 1: Treatment of MDR-LTBI.

\begin{tabular}{|c|c|c|}
\hline Resistance Pattern & $\begin{array}{c}\text { Drug-Resistant LTBI Treatment } \\
\text { options }\end{array}$ & $\begin{array}{l}\text { Treatment } \\
\text { duration* }\end{array}$ \\
\hline $\begin{array}{c}\text { INH: Resistant } \\
\text { Rifampicin: Susceptible }\end{array}$ & Rifampicin & 6 months \\
\hline INH \& Rifampicin: Resistant & $\begin{array}{l}\text { Fluoroquinolone or } \\
\text { Fluoroquinolone + Ethambutol }\end{array}$ & 6-12 months \\
\hline $\begin{array}{c}\text { INH, Rifampicin \& Ethambutol: } \\
\text { Resistant }\end{array}$ & $\begin{array}{l}\text { Fluoroquinolone or } \\
\text { Fluoroquinolone + Ethionamide }\end{array}$ & 6-12 months \\
\hline $\begin{array}{c}\text { INH, Rifampicin \& } \\
\text { Pyrazinamide: Resistant }\end{array}$ & $\begin{array}{l}\text { Fluoroquinolone or } \\
\text { Fluoroquinolone + Ethambutol }\end{array}$ & 6-12 months \\
\hline $\begin{array}{l}\text { INH, Rifampicin Pyrazinamide } \\
+ \text { +/- second line Injectable }\end{array}$ & $\begin{array}{l}\text { Fluoroquinolone or } \\
\text { Fluoroquinolone + Ethionamide }\end{array}$ & 6-12 months \\
\hline $\begin{array}{c}\text { INH, Rifampicin Pyrazinamide, } \\
\text { second-line Injectable, } \\
\text { Ethionamide }\end{array}$ & $\begin{array}{l}\text { Fluoroquinolone or } \\
\text { Fluoroquinolone + cycloserine (CS) }\end{array}$ & 6-12 months \\
\hline $\begin{array}{l}\text { INH, Rifampicin Pyrazinamide, } \\
\text { Ethambutol and } \\
\text { fluoroquinolone }\end{array}$ & $\begin{array}{l}\text { No treatment, clinical monitoring } \\
\text { (In select cases, Cycloserine }+ \\
\text { para-aminosalicylic acid [PAS] or } \\
\text { PAS + Ethionamide or } \\
\text { Ethionamide + Cycloserine may be } \\
\text { considered) }{ }^{\star \star}\end{array}$ & 6-12 months \\
\hline
\end{tabular}

INH, Rifampicin

Fluoroquinolone: Resistant [9]

Pyrazinamide and Ethambutol: Sensitive

Pyrazinamide+ Ethambutol [9] 6-12 months

*Minimum treatment duration of MDR-LTBI treatment should be six months in lowerrisk individuals and twelve months in PLHIV, children, and other individuals with medical risk factors.

**Based on the source case TB isolate's drug sensitivity pattern, the regime can be designed

\section{References}

1. Knight GM, McQuaid CF, Dood PJ, Houben MGJ (2019) The global burden of multi-drug resistant latent Tuberculosis: recent trends and estimates using mathematical modelling. Lancet Infect Dis 19: 903-912. Link: https://bit.ly/3pQdSOt

2. Pollock NR, Kashino SS, Napolitano DR, Sloutsky A, Joshi S, et al. (2019) Evaluation of the effect of treatment of latent tuberculosis infection on QuantiFERON-TB gold assay results. Infect Control Hosp Epidemiol 30: 392 395. Link: https://bit.ly/3kUSKTu

3. Espinal M (2004) What is the "fall and rise" phenomenon and the "sequential regimen" mechanism? In: Frieden T, editor. Toman's Tuberculosis: case detection, treatment, and monitoring - questions and answers. 2nd ed Geneva, Switzerland: World Health Organization 200-202.

4. World Health Organisation (2018) Latent TB Infection: Updated and consolidated guidelines for programmatic management. Geneva, Switzerland. Link: https://bit.ly/3kRJwrj

5. Padmapriyadarsini C, Shobana M, Lakshmi M, Beena T, Swaminathan S (2016) Undernutrition \& Tuberculosis in India: Situation analysis \& the way forward Indian J Med Res 144: 11-20. Link: https://bit.ly/36XVFWx

6. Murray JF (2015) The Industrial Revolution and the decline in death rates from Tuberculosis. Int J Tuberc Lung Dis 19: 502-503. Link: https://bit.ly/2HptZkD

Citation: Mishra G, Mulani J (2020) Latent Multi-drug Resistant Tuberculosis: An Unaddressed Problem. Arch Pulmonol Respir Care 6(1): 084-086. 
7. Marks SM, Mase SR, Morris SB (2017) Systematic review, meta-analysis, and cost-effectiveness of treatment of latent Tuberculosis to reduce progression to multidrug-resistant Tuberculosis. Clin Infect Dis 64: 1670-1677. Link: https://bit.ly/2HpRj1G

8. Migliori GB, Tiberi S, Zumla A, Petersen E, Chakaya JM, et al. (2020) MDR/XDRTB management of patients and contacts: Challenges facing the new decade. The 2020 clinical update by the Global Tuberculosis Network. Int J Infect Dis 92: S15- S25. Link: https://bit.ly/3kWgXcj
9. Nahid P, Mase SR, Migliori GB, Sotgiu G, Bothamley GH, et al. (2019) Treatment of drug-resistant Tuberculosis an official ATS/CDC/ERS/IDSA clinical practice guideline. Am J Respir Crit Care Med 200: E93-E142. Link: https://bit.ly/39671KX

10. Curry International Tuberculosis Center and California Department of Public Health (2016) Drug-Resistant Tuberculosis: A Survival Guide for Clinicians, Third Edition. 3rd ed. 278-294. Link: https://bit.ly/3fotpQM

\section{Discover a bigger Impact and Visibility of your article publication with}

\section{Peertechz Publications}

\section{Highlights}

* Signatory publisher of ORCID

* Signatory Publisher of DORA (San Francisco Declaration on Research Assessment)

* Articles archived in worlds' renowned service providers such as Portico, CNKI, AGRIS, TDNet, Base (Bielefeld University Library), CrossRef, Scilit, J-Gate etc.

* Journals indexed in ICMJE, SHERPA/ROMEO, Google Scholar etc.

* OAI-PMH (Open Archives Initiative Protocol for Metadata Harvesting)

* Dedicated Editorial Board for every journal

* Accurate and rapid peer-review process

* Increased citations of published articles through promotions

* Reduced timeline for article publication

Submit your articles and experience a new surge in publication services (https://www.peertechz.com/submission).

Peertechz journals wishes everlasting success in your every endeavours

Copyright: @ 2020 Mishra G, et al. This is an open-access article distributed under the terms of the Creative Commons Attribution License, which permits unrestricted use distribution, and reproduction in any medium, provided the original author and source are credited. 